\title{
BMR
}

\section{Genetic gains from selection for fiber traits in Gossypium hirsutum $L$.}

G.M.P. de Faria ${ }^{1}$, C.F.B. Sanchez ${ }^{2}$, L.P. de Carvalho ${ }^{3}$, M. da Silva Oliveira and C.D. Cruz ${ }^{1}$

${ }^{1}$ Laboratório de Bioinformática, Departamento de Biologia, Universidade Federal de Viçosa, Viçosa, MG, Brasil

${ }^{2}$ Universidade de Caldas, Manizales, Colômbia

${ }^{3}$ Embrapa Algodão, Campina Grande, PB, Brasil

Corresponding author: G.M.P. de Faria

E-mail: gislaynemaira@yahoo.com.br

Genet. Mol. Res. 15 (4): gmr15048146

Received November 25, 2016

Accepted September 30, 2016

Published November 21, 2016

DOI http://dx.doi.org/10.4238/gmr15048146

Copyright $(2016$ The Authors. This is an open-access article distributed under the terms of the Creative Commons Attribution ShareAlike (CC BY-SA) 4.0 License.

\begin{abstract}
Brazil is among the five largest producers of cotton in the world, cultivating the species Gossypium hirsutum L. r. latifolium Hutch. The cultivars should have good fiber quality as well as yield. Genetic improvement of fiber traits requires the study of the genetic structure of the populations under improvement, leading to the identification of promising parent plants. To this end, it is important to acquire some information, such as estimates of genetic variance components and heritability coefficients, which will support the appropriate choice of the breeding strategy to be employed as well as enable the estimation of gains from selection. This study aimed to evaluate some agronomic characteristics, such as fiber quality and yield, estimating genetic parameters for the purpose of predicting earnings. Twelve cultivars of cotton, including four male progenitors (CNPA 01-42, BRS Verde, Glandless, and Okra leaf) and eight female progenitors (Delta opal, CNPA 7H, Aroeira, Antares, Sucupira, Facual, Precoce 3, and CNPA 8H), were used in performing crosses according to design I, proposed by Comstock
\end{abstract}


and Robinson (1948). The experimental design was a randomized block with four replications. We observed genetic variability among all traits as well as higher efficiency of selection for the gains related to traits. Our results showed that the combined selection presented the highest genetic gains for all traits. For fiber length, the female/male selection and the combined selection resulted in the highest genetic gain.

Key words: Cotton; Fiber; Predicted gains

\section{INTRODUCTION}

Brazil is among the five largest cotton producers in the world, cultivating the species Gossypium hirsutum L. r. latifolium Hutch. According to Instituto Brasileiro de Geografia e Estatística (IBGE, 2016), cotton production in Brazil has grown every year, producing more than 4.0 million tons of cotton annually.

One of the most important textile fibers in the world is produced from cotton. It generates various products that have relevance in the Brazilian and world economies. It is considered one of the most useful plants, making cotton-related businesses one of the ten largest sources of wealth for Brazilian agribusiness. Despite competition from synthetic fibers derived from petroleum, cotton supplies approximately $50 \%$ of the world textile industry (Santos et al., 2008; Queiroz et al., 2011).

Cotton breeding programs seek, as primary objectives, an increase in yield, improvement in fiber quality, and resistance to pests and diseases (Preetha and Raveendren, 2008). In accordance with the requirements of the textile industry, the cotton cultivars should have high fiber quality and yield. The main characteristics preferred by the industries are fiber length, low short fiber content, high uniformity of fiber length and lower variation of fiber properties (Smith et al., 2008). The desired fiber length, in accordance with the international standards, has been $27.8 \mathrm{~mm}$, for cotton of average fiber properties (Braden and Smith, 2004).

Genetic improvement of fiber traits requires the study of the genetic structure of the populations under improvement and subsequent identification of parent plants with superior traits. To this end, it is important to acquire information, such as estimates of genetic variance components and heritability coefficients, which will support the appropriate choice of breeding strategy as well as enable the estimation of gains from selection (Aguiar, 2003). For a breeder, one considerably important practice is the selection of superior phenotypes of either individuals or families, as acquisition of improved populations requires selection and recombination of individuals or families (Neves et al., 2011).

Once the existence of variability has been confirmed in the studied population, different strategies should be used to select the best genotypes, thus maximizing the gain of selection by employing genetic design I, defined by Comstock and Robinson (1948). Design I is useful in generating the estimates of genetic parameters and constitutes a good breeding strategy by enabling one to simultaneously evaluate full-sib and half-sib families and to infer the potential of parents. It is used to estimate the genetic variance components and genetic parameters in the study populations (Hallauer et al., 1988; Cruz and Carneiro, 2003).

Genetic design I is based on the formation of the initial progenies of full-sib and halfsib families through controlled pollination between one group of male parents and different groups female parents. The layouts of the families of this design enable the adoption of different selection strategies such as selection among males, females, and females hierarchized

Genetics and Molecular Research 15 (4): gmr15048146 
to males, and combined selection (Cruz and Carneiro, 2003). Design I has been used relatively less in cotton cultivation; however, it is more frequently used with other crops such as maize (Hallauer et al., 1988; Eyherabide and Hallauer, 1991; Furtado, 1996) and yellow passion fruit (Gonçalves et al., 2007; Neves et al., 2011).

The present study aimed to evaluate all agronomic traits important for the acquisition of quality fibers and to estimate the genetic parameters for the purpose of predicting gains. It also aimed to evaluate the responses to selection and estimate the gains from alternative selection strategies structured in Design I.

\section{MATERIAL AND METHODS}

Twelve cultivars of cotton G. hirsutum L. r. latifolium Hutch. were used in this study. Of these, four male progenitors (CNPA 01-42, BRS Verde, Glandless, and Okra leaf) and eight female progenitors (Delta opal, CNPA 7H, Aroeira, Antares, Sucupira, Facual, Precoce 3, and CNPA 8H) were used for performing crosses using Design I in Campina Grande, Paraíba, Brazil. The cultivars used as female progenitors were among those that were recommended for planting in Cerrados in 2005 because of their superior agronomic traits. Those used as male progenitors had special traits, such as brown- or green-colored fibers, okra leaf, and glandless, which served as gene markers in order to identify their $F_{1}$ progenies as shown in Table 1. All gene markers exhibited complete dominance among the alleles and the F1 plants displayed the corresponding phenotype. Each male progenitor was crossed with two different cultivars. The $F_{1}$ seeds of the said crossings were planted under furrow irrigation conditions in a field at the experimental station of the Brazilian Agricultural Research Corporation (Embrapa), Barbalha, Ceará, Brazil.

Table 1. Crossings carried out between 12 cultivars of cotton.

\begin{tabular}{l|l}
\hline Treatments & Crossings \\
\hline 1 & CNPA 01-42 x Delta opal \\
\hline 2 & CNPA 01-42 x CNOA 7H \\
\hline 3 & BRS VERDE x Aroeira \\
\hline 4 & BRS VERDE x Antares \\
\hline 6 & Glandless x Sucupira \\
\hline 7 & Glandless x Facual \\
\hline 8 & Okraleaf x Precoce 3 \\
\hline
\end{tabular}

A randomized block experimental design with four replicates was used. Each plot comprised of rows, $5 \mathrm{~m}$ in length and spaced from each other by a distance of $1.0 \mathrm{~m}$. Each row contained 30-35 plants. The yield ( $\mathrm{kg} / \mathrm{ha}$ ) was determined for each plot and the fiber traits were determined in the samples of 20 bolls harvested from each plot. The following fiber traits were determined: final stand (STF), percentage of fiber (PF; \%), average weight of bolls (PC; g), fiber length (COMP), uniformity of length (UNI; \%), short fiber index (SFI), fiber resistance (RES; gf/ tex), elongation (ELG; \%), fineness of fiber (FIN; micronaire), and maturity (MAT; \%).

For statistical analyses of the data, we performed the analyses of variance of all evaluated traits, initially considering only the treatment effects, and then randomly considering the effects of the genetic-statistic model described below:

$$
Y_{i j k}=m+M_{i}+F / M_{i j}+\varepsilon_{i j k}
$$

where $Y_{i j \mathrm{k}}$ is the observation in the $k^{\text {th }}$ resultant descendant of the cross of the $i^{\text {th }}$ male with the 
$j^{\text {th }}$ female; $M_{i}$ is the effect of the $i^{\text {th }}$ male, $\mathrm{i}=1,2, \ldots \mathrm{m}$, and $\mathrm{M}_{\mathrm{i}} \sim \mathrm{NID}\left(0, \sigma_{m}^{2}\right) ; F / m_{i j}$ is the effect of the $j^{\text {th }}$ female within that of the $i^{\text {th }}$ male $\mathrm{j}=1,2 \ldots . \mathrm{M}_{\mathrm{i}}$, and $F / M_{i j} \sim \mathrm{NID}\left(0, \sigma_{f / m}^{2}\right) ; \varepsilon_{i j k}$ is the effect of the $k^{\text {th }}$ descendant of the $i^{\text {th }}$ male and $j^{\text {th }}$ female $\left(\mathrm{k}=1,2 \ldots \mathrm{n}\right.$, and $\left.\varepsilon_{i j k}=\sim \mathrm{NID}\left[0, \sigma_{d}^{2}\right]\right)$;

The layout of the analysis of variance, on the total-plot level, with the mean squares and expected mean squares of treatment, males, females, and descendants in accordance with genetic design I are presented in Table 2.

Table 2. Layout of the analysis of variance, with the square averages and their respective expected values of the square averages, following design I proposed by Comstock and Robinson (1948).

\begin{tabular}{l|l|l|l}
\hline Sources & d.f. & MS & $\mathrm{E}(\mathrm{MS})$ \\
\hline Treatment & $\mathrm{mf}-1$ & MS & $\sigma_{d}^{2}+n \sigma_{f / m}^{2}+n \frac{m f-f}{m f-1} \sigma_{m}^{2}$ \\
\hline Males & $\mathrm{m}-1$ & MS & $\sigma_{d}^{2}+n \sigma_{f / m}^{2}+n f \sigma_{m}^{2}$ \\
\hline Females/Males & $\mathrm{m}(\mathrm{f}-1)$ & MSF & $\sigma_{d}^{2}+n \sigma_{f / m}^{2}$ \\
\hline Descendants/Females/Males & $(\mathrm{n}-1) \mathrm{mf}$ & MS & $\sigma_{d}^{2}$ \\
\hline
\end{tabular}

d.f. $=$ degrees of freedom; $\mathrm{MS}=$ mean squares; $\mathrm{E}(\mathrm{MS})=$ error mean squares.

The genetic gains were estimated considering the following alternatives of the selection derived from design I (Furtado, 1996; Cruz and Carneiro, 2003): selection based on the average of males, selection based on the average of females, selection based on the average of females hierarchized to males, and combined selection. To acquire the estimate of gain, the following general expression was used:

$$
G S=h^{2} D S
$$

where GS is the gain by selection, DS is the selection differential, and $\mathrm{h}^{2}$ is the heritability defined as a function of the selection strategy used, in accordance with the following structure:

Selection based on the average of males, with progenies arising from females pollinated by the same individual:

$$
\begin{gathered}
h_{M(A)}^{2}=\frac{\hat{\sigma}_{m}^{2}+\left(\hat{\sigma}_{f / m}^{2} / f\right)}{M S_{m} / r f} \\
h_{M(R)}^{2}=\left(\frac{f+1}{4 f} \hat{\sigma}_{A}^{2}\right) / \frac{M S_{M}}{r f}
\end{gathered}
$$

Selection based on the average of females, irrespective of the males that they belonged to:

$$
h_{F(A)}^{2}=\frac{\frac{f(m-1)}{m f-1} \hat{\sigma}_{m}^{2}+\hat{\sigma}_{f}^{2}}{\hat{\sigma}_{F / m}^{2}}
$$

where 


$$
\begin{aligned}
& \hat{\sigma}_{F f m}^{2}=\frac{(m-1) \mathrm{MS}_{M}+m(f-1) M S_{F}}{n(m f-1)} \\
& h_{F(R)}^{2}=\left(\frac{2 m f-f-1}{m f-1} \times \frac{1}{4} \hat{\sigma}_{A}^{2}\right) / \frac{M S_{p}}{r}
\end{aligned}
$$

Selection based on the average of females hierarchized, in which families of females hierarchized to the same males were selected:

$$
h_{F / M(A)}^{2}=\frac{\hat{\sigma}_{f / m}^{2}}{\hat{\sigma}_{F f}^{2}}
$$

where

$$
\begin{gathered}
\hat{\sigma}_{F f}^{2}=\frac{M S_{F}}{r} \\
h_{F / M(R)}^{2}=\left(\frac{1}{4} \hat{\sigma}_{A}^{2}\right) / \frac{M S_{F / M}}{r}
\end{gathered}
$$

As previously described, $h_{M}^{2}, h_{F}^{2}$, and $h_{F / M}^{2}$ are the coefficients of heritability in the broad and narrow sense, in regard to the average of males, average of females, and average of females hierarchized to males, respectively; $\mathrm{r}$ and $\mathrm{f}$ are the number of repetitions and number of females, respectively; $\sigma_{A}^{2}$ is the estimate of the component of additive genetic variance; $\mathrm{MS}_{\mathrm{M}}, \mathrm{MS}_{\mathrm{F}}$, and $\mathrm{MS}_{\mathrm{F} / \mathrm{M}}$ are the mean squares of the effects of males, females, and females hierarchized to the males, respectively.

The combined index was obtained through the following estimator:

$$
I C=h_{M}^{2}\left(\bar{Y}_{m \ldots}-\bar{Y}_{\ldots}\right)+\mathrm{h}_{F / M}^{2}\left(\bar{Y}_{m f .}-\bar{Y}_{m . .}\right)
$$

where $\bar{Y}_{\text {... }}$ is the general average; $\bar{Y}_{m . . .}$ is the average of the $m$ th male; and $\bar{Y}_{m f}$ is the average of the $f^{\text {th }}$ female mated with the $m^{\text {th }}$ male.

In this study, we assessed the selection alternatives derived from design I in cotton. The Genes program was used for all calculations of the predicted gains (Cruz, 2013).

Genetics and Molecular Research 15 (4): gmr15048146 


\section{RESULTS AND DISCUSSION}

The results of the variance analyses, overall average, and variance coefficient (CV) relative to the evaluated traits are presented in Table 3 . The analysis of variance revealed the existence of genetic variance among the full-sib and half-sib progenies, indicating the existence of genetic variability among parents, which is quite favorable to the improvement in the average in which genetic heterogeneity in the population enables the acquisition of gains through selection techniques. The F-test showed non-zero genetic variance in relation to the traits PF, COMP, UNI, ELG, FIN, and MAT, considering the effect of males significant to the level of females/males, for PF and PC to $1 \%$ probability and COMP and FIN to 5\% probability (Table 3 ).

Table 3. Summary of the variance analyses of the traits evaluated in cotton progenies established from the crossings, following design I proposed by Comstock and Robinson (1948).

\begin{tabular}{|c|c|c|c|c|c|c|c|c|c|c|c|c|}
\hline \multirow[t]{2}{*}{ Sources } & \multirow[t]{2}{*}{ d.f. } & \multicolumn{11}{|c|}{ Mean square } \\
\hline & & STF & REN & $\mathrm{PF}$ & $\mathrm{PC}$ & COMP & UNI & SFI & RES & ELG & FIN & MAT \\
\hline Block & 3 & 15.36 & $490,611.69$ & 0.45 & 0.08 & 0.52 & 0.91 & 0.02 & 0.96 & 2.21 & 0.05 & 0.94 \\
\hline Male & 3 & $5.28^{\mathrm{ns}}$ & $363,795.53^{\mathrm{ns}}$ & $49.85 *$ & $0.12^{\mathrm{ns}}$ & $12.11 * *$ & $9.50^{*}$ & $1.82^{\mathrm{ns}}$ & $8.11^{\mathrm{ns}}$ & $7.35^{*}$ & $1.39^{*}$ & $6.61^{*}$ \\
\hline F/M & 4 & $3.65^{\mathrm{ns}}$ & $843,489.03^{\text {ns }}$ & $5.93 * *$ & $0.60 * *$ & $0.59 *$ & $1.10^{\mathrm{ns}}$ & $0.75^{\mathrm{ns}}$ & $2.29^{\mathrm{ns}}$ & $0.53^{\mathrm{ns}}$ & $0.14 *$ & $0.78^{\mathrm{ns}}$ \\
\hline Residual & 21 & 3.50 & $534,857.69$ & 0.81 & 0.11 & 0.20 & 1.67 & 0.29 & 5.36 & 1.45 & 0.04 & 1.35 \\
\hline Average & & 33.15 & $2,411.21$ & 37.81 & 6.11 & 29.50 & 84.64 & 3.45 & 26.36 & 8.76 & 4.27 & 87.84 \\
\hline CV (\%) & & 5.64 & 30.33 & 2.03 & 5.46 & 1.54 & 1.52 & 15.70 & 8.78 & 13.77 & 5.08 & 1.32 \\
\hline
\end{tabular}

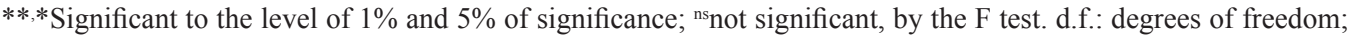
CV: coefficient of variance; STF: final stand; REN: yield; PF: percentage of fiber; PC: average weight of bolls; COMP: fiber length; UNI: uniformity of length; SFI: index of short fibers; RES: fiber resistance; ELG: elongation; FIN: fineness of fiber; and MAT: maturity.

The CVs obtained for these 11 traits were not high, except for the yield (REN), evidencing good experimental precision. The traits that exhibited the greatest values were REN, SFI, and ELG, with $30.33,15.70$, and $13.77 \%$, respectively, being possibly the most influenced by the environment. The other evaluated traits had values below $8.8 \%$ (Table 3 ).

Table 4 presents the estimates of variance components associated with the random effects of the nature of the statistical model and coefficients of additive genetic variance

Table 4. Estimate of the variance components associated with the random effects of the statistical model, relative to the 11 traits.

\begin{tabular}{l|c|c|c|c|c|c}
\hline Traits & $\sigma_{m}^{2}$ & $\hat{\sigma}_{f / m}^{2}$ & $\hat{\sigma}_{g}^{2}$ & $\hat{\sigma}_{A}^{2}$ & $\sigma_{D}^{2}$ & $\mathrm{CVa}(\%)$ \\
\hline STF & 0.2031 & 0.0372 & 0.2403 & 0.8125 & -0.6637 & 2.71 \\
\hline REN & 0 & 77157.83 & 77157.83 & 0 & 308631.33 & 0 \\
\hline PF & 5.4897 & 1.2809 & 6.7706 & 21.9589 & -16.8351 & 12.39 \\
\hline PC & 0 & 0.1229 & 0.1229 & 0 & 0.4916 & 0 \\
\hline COMP & 1.4393 & 0.0974 & 1.5393 & 5.7572 & -5.3674 & 8.13 \\
\hline SFI & 1.0496 & 0 & 10496 & 4.1984 & -4.1984 & 2.48 \\
\hline RES & 0.1342 & 0.1146 & 0.2488 & 0.537 & -0.0786 & 21.20 \\
\hline ELG & 0.727 & 0 & 0.727 & 2.9078 & -2.9078 & 6.46 \\
\hline FIN & 0.8517 & 0 & 0.8517 & 3.407 & -3.407 & 21.05 \\
\hline MAT & 0.156 & 0.0245 & 0.1805 & 0.6242 & -0.5262 & 18.46 \\
\hline
\end{tabular}

$\hat{\sigma}_{m}^{2}, \hat{\sigma}_{f / m}^{2}$ and $\hat{\sigma}_{g}^{2}$ represent the effects of the male parent, female parent related to the male, and effect of the progeny, respectively. $\hat{\sigma}_{A}^{2}$ and $\hat{\sigma}_{D}^{2}$ represent the estimates of the genetic variance components between the individuals of the population and additive genetic variance attributed to the standards of the dominance, respectively. $\mathrm{CV}_{a} \sqrt{\hat{\sigma}_{a}^{2} / m}$ represents the estimates of the component of additive genetic variance $\hat{\sigma}_{g}^{2}=\hat{\sigma}_{m}^{2}+\hat{\sigma}_{f / m}^{2}$. 
among individuals of the reference population. From the variance components, we estimated the additive genetic variance $\hat{\sigma}_{A}^{2}=4 \hat{\sigma}_{m}^{2}$ and the genetic variance due to the deviation of the dominance $\hat{\sigma}_{D}^{2}=4\left(\hat{\sigma}_{f}^{2}-\hat{\sigma}_{m}^{2}\right)$.

The analysis of the data presented in Table 4 shows that a negative $\hat{\sigma}_{D}^{2}$ value was obtained for the traits STF, PF, COMP, UNI, SFI, RES, ELG, FIN, and MAT. The negative estimate for each trait was considered null, showing the additive nature of the genotypic variance of all traits. The trait REN highlighted itself by presenting the highest value of $\hat{\sigma}_{D}^{2}$.

According to Falconer (1987), the additive genetic variance is the primary measure of similarity among relatives, as it is measured from the heritable genetic variation. Thus, it is the main determinant of the genetic properties of a population and its response to selection. This variance can be defined as the double gametic variability, which is expressed by the additive effects of alleles (Falconer and Mackay, 1996; Cruz and Carneiro, 2003). The trait PF showed the highest $\sigma_{m}^{2}$ and coefficient of additive genetic variation $\left(\mathrm{CV}_{\mathrm{a}}\right)$ values (Table 4), indicating that this trait could provide the highest selection response during the process of long-term selection in this population.

$\mathrm{CV}_{\mathrm{a}}$ corresponds to the additive gentetic standard deviation in percentage of the average, and is an indicator of the relative magnitude of the changes that can be obtained through selection for each trait throughout the breeding program (Furtado, 1996). In this study, it was not possible to determine the estimate of $\sigma_{A}^{2}$ for the traits REN and PC since $\sigma_{m}^{2}=0$ for both. Carvalho (1995) analyzed the genetic control of the traits PF and PC and found the significance of variation caused by the additive genetic action of these two traits with average heritability of $60 \%$, which enabled the selection of promising strains of cotton in the segregant generations.

The heritability is a fraction of the phenotypic variability among the units of selection caused by the genetic differences between them. The results of the different coefficients of heritability, in the broad sense, are presented in Table 5.

Table 5. Coefficients of broad-sense heritability, considering units of selection, male families, female families, and families of females within families of males of cotton, relative to the eleven traits studied.

\begin{tabular}{l|c|c|c|c|c|c|c|c|c|c|c}
\hline & STF & REN & PF & PC & COMP & UNI & SFI & RES & ELG & FIN & MAT \\
\hline$h_{M(A)}^{2}$ & 33.59 & 84.84 & 98.37 & 38.71 & 98.28 & 88.34 & 83.87 & 71.68 & 92.68 & 96.66 & 88.19 \\
\hline$h_{F / M(A)}^{2}$ & 4.07 & 36.59 & 86.34 & 81.46 & 65.13 & 0 & 60.87 & 0 & 0 & 67.42 & 0 \\
\hline$h_{F(A)}^{2}$ & 19.42 & 36.59 & 96.73 & 81.46 & 96.23 & 68.21 & 75.71 & 31.7 & 66.68 & 93.04 & 64.89 \\
\hline
\end{tabular}

$h_{M(A)}^{2}=$ heritability on the level of male average in the broad sense. $h_{F / M(A)}^{2}=$ heritability on the level of female average within that of male in the broad sense. $h_{F(A)}^{2}=$ heritability on the level of broad-sense female average.

For all evaluated traits, the coefficients of heritability in the level of males were higher than those in the levels of females and females within those of males; these values varied between $33.59 \%$ for STF to $98.37 \%$ for PF. High heritability values can occur in traits of little additive genetic variance because they are not much influenced by the environment (Neves et al., 2011). Similarly, de Magalháes Bertini et al. (2006) reported that the more elevated broad-sense heritability values, relative to the said traits, indicated greater influence of the non-additive and environmental effects. The higher the heritability, the closer it will be to the expected response of the selection differential 
employed. Ali et al. (2008) studied the fiber quality in G. hirsutum L. and reported that the additive variance would be significant for all evaluated traits and relatively less than the dominance for length, resistance, fineness, uniformity, and elongation. Riaz et al. (2013) conducted studies on various features of the five elite cotton lines of G. hirsutum. They recorded considerable genotypic variation among the genotypes and heritability estimates in the broad sense for all evaluated traits.

In Table 6, the estimates of the gains predicted through direct selection are presented for various alternatives of selection. We observed the lowest predicted gains for selection among males and the highest for the combined selection alternative. These results agreed with the results of Falconer (1987) and Gonçalves et al. (2007), affirming that the selection based on the combined indices is better or superior than the other methods of predicting gains.

Table 6. Estimates of the predicted gains for cotton traits (in percentage).

\begin{tabular}{l|c|c|c|c|c|c}
\hline Alternative of selection & PF & COMP & UNI & ELG & FIN & MAT \\
\hline $\mathrm{a}$ & 2.4116 & 1.1719 & 0.9897 & 0.8863 & 0.4493 & 0.7854 \\
\hline $\mathrm{b}$ & 2.4514 & 2.1946 & 1.1008 & 1.2662 & 0.4966 & 1.05 \\
\hline $\mathrm{c}$ & 3.0166 & 1.6848 & 1.2701 & 1.0203 & 0.5697 & 1.0105 \\
\hline $\mathrm{d}$ & 3.7952 & 2.2419 & 1.6928 & 1.6612 & 0.6907 & 1.4028 \\
\hline
\end{tabular}

Selection among males (a), females/males (b), females independent of males (c), and combined selection (d).

For COMP trait, the female/male and combined selection alternatives resulted in higher genetic gain, with values of 2.19 and 2.24, respectively. On the other hand, no genetic gain was observed for PC in view of the null value detected for the additive genetic variance (Table 5). The fiber length is critical for the textile industry and varies greatly among the types of cotton due to their genetic differences (Basra, 2000). In some previous studies, authors have reported little or no genetic gain in fiber length (Miller and Rawlings, 1967; Bridge et al., 1971; Bridge and Meredith, 1983; Culp and Green, 1992). Schwartz and Smith (2008) have reported progress in the improvement of fiber length with the release of new cultivars in the USA.

Table 7 shows the results of the different alternatives of selection in relation to the crosses performed for the seven significant agronomic traits. Therefore, according to the evaluation of the different selection alternatives, the best crosses for PF were between the Glandless male and the Sucupira female and between the Okra leaf male and the Precoce 3 female, since these crosses produce progenies with a greater percentage of fiber. For UNI, the best crosses, as indicated by the alternatives of selection, occurred between the Okra leaf male and the CNPA $8 \mathrm{H}$ female and between the BRS verde male and the Atares female. For PC, the only cross that led to the same result for all alternatives of selection occurred between the BRS verde male and the Aroeira female. However, for ELG, the best crosses were indicated between the CNPA01-42 male and the CNPA 7H female or between the Glandless male and the Facual female. For COMP, the best crosses occurred between the BRS verde male and the Antares female or between the Okra leaf male and the Precoce 3 female. For MAT, the crosses were indicated between the Glandless male and the Sucupira female, the Okra leaf male and the Sucupira female, and the Okra leaf male and the CNPA $8 \mathrm{H}$ female. According to Table 6, the combined selection alternative provided the highest predicted gains.

Genetics and Molecular Research 15 (4): gmr15048146 
Table 7. Families of cotton indicated as superior in different selection strategies, in relation to the seven agronomic traits.

\begin{tabular}{|c|c|c|c|c|c|c|c|c|c|c|c|c|c|c|c|c|c|}
\hline \multicolumn{9}{|c|}{$\mathrm{PF}$} & \multicolumn{9}{|c|}{ UNI } \\
\hline \multirow[t]{2}{*}{ Males } & \multicolumn{8}{|c|}{ Females } & \multirow[t]{2}{*}{ Males } & \multicolumn{8}{|c|}{ Females } \\
\hline & 1 & 2 & 3 & 4 & 5 & 6 & 7 & 8 & & 1 & 2 & 3 & 4 & 5 & 6 & 7 & 8 \\
\hline CNPA $01-42$ & bcd & & & & & & & & CNPA01-42 & & $\mathrm{b}$ & & & & & & \\
\hline BRS verde & & & $\mathrm{b}$ & & & & & & BRS verde & & & $\mathrm{a}$ & abcd & & & & \\
\hline Glandless & & & & & abcd & $\mathrm{a}$ & & & Glandless & & & & & bcd & & & \\
\hline Okra leaf & & & & & & & abcd & acd & Okra leaf & & & & & & & acd & abcd \\
\hline \multicolumn{9}{|l|}{ PC } & \multicolumn{9}{|l|}{ ELG } \\
\hline \multirow[t]{2}{*}{ Males } & \multicolumn{8}{|c|}{ Females } & Males & \multicolumn{8}{|c|}{ Females } \\
\hline & 1 & 2 & 3 & 4 & 5 & 6 & 7 & 8 & & 1 & 2 & 3 & 4 & 5 & 6 & 7 & 8 \\
\hline CNPA $01-42$ & d & bcd & & & & & & & CNPA $01-42$ & acd & abcd & & & & & & \\
\hline BRS verde & & & abcd & ad & & & & & BRS verde & & & bcd & & & & & \\
\hline Glandless & & & & & $a b c$ & $\mathrm{a}$ & & & Glandless & & & & & $\mathrm{a}$ & abcd & & \\
\hline Okra leaf & & & & & & & & $\mathrm{bc}$ & Okra leaf & & & & & & & & $\mathrm{b}$ \\
\hline \multicolumn{9}{|l|}{ COMP } & \multicolumn{9}{|l|}{ FIN } \\
\hline \multirow[t]{2}{*}{ Males } & \multicolumn{8}{|c|}{ Females } & \multirow[t]{2}{*}{ Males } & \multicolumn{8}{|c|}{ Females } \\
\hline & 1 & 2 & 3 & 4 & 5 & 6 & 7 & 8 & & 1 & 2 & 3 & 4 & 5 & 6 & 7 & 8 \\
\hline CNPA 01-42 & & $\mathrm{b}$ & & & & & & & CNPA 01-42 & bcd & $\mathrm{c}$ & & & & & & \\
\hline BRS verde & & & $\mathrm{a}$ & abcd & & & & & BRS verde & & & $a b$ & $\mathrm{a}$ & & & & \\
\hline Glandless & & & & & bed & & & & Glandless & & & & & $\mathrm{cd}$ & bcd & & \\
\hline Okra leaf & & & & & & & abcd & acd & \multirow[t]{8}{*}{ Okra Iedi } & & & & & & & $\mathrm{a}$ & abd \\
\hline \multicolumn{9}{|l|}{ MAT } & & & & & & & & & \\
\hline \multirow[t]{2}{*}{ Males } & \multicolumn{8}{|c|}{ Females } & & & & & & & & & \\
\hline & 1 & 2 & 3 & 4 & 5 & 6 & 7 & 8 & & & & & & & & & \\
\hline CNPA 01-42 & bcd & & & & & & & & & & & & & & & & \\
\hline BRS verde & & & $\mathrm{b}$ & & & & & & & & & & & & & & \\
\hline Glandless & & & & & abcd & ac & & & & & & & & & & & \\
\hline Okra leaf & & & & & & & $\mathrm{a}$ & abcd & & & & & & & & & \\
\hline
\end{tabular}

$\mathrm{a}=$ Selection between males; $\mathrm{b}=$ selection of females/males; $\mathrm{c}=$ section between females (independent of males); $\mathrm{d}$ $=$ combined selection females; $1=$ Delta opal; $2=\mathrm{CNPA} 7 \mathrm{H} ; 3=$ Aroeira; $4=$ Antares; $5=$ Sucupira; $6=\mathrm{p}$ Facual; $7=$ Precoce $3 ; 8=$ CNPA.

\section{CONCLUSION}

Genetic variability exists for the fiber traits among the progenitors. No dominance variance was detected for the evaluated traits PF, COMP, UNI, SFI, RES, ELG, FIN, and MAT. Only genotypic variance of the additive nature was detected for these traits. The trait PF exhibited the highest additive genotypic variance, indicating that it enables the highest selection response. The combined selection alternative presented the highest genetic gains for all traits. For COMP, the female/male selection and the combined selection resulted in the highest genetic gains.

\section{Conflicts of interest}

The authors declare no conflict of interest.

\section{ACKNOWLEDGMENTS}

The authors would like to thank Professor Cosme Damião Cruz from the Department of Biology at Universidade Federal de Viçosa, for his helpful advice and proofreading the English style of our manuscript. Research supported by Coordenação de Aperfeiçoamento de Pessoal de Nível Superior (CAPES), Brazil, Conselho Nacional de Desenvolvimento Científico e Tecnológico (CNPq), Brazil, and Embrapa Cotton, Brazil. 
G.M.P. de Faria et al.

\section{REFERENCES}

Aguiar AM (2003). Use of the design III with molecular markers for the genetic analysis of grain yield and its components in maize. PhD thesis. Escola Superior de Agricultura Luiz de Queiroz, Piracicaba.

Akhtar MM, Azhar FM and Ali Z (2008). Genetic basis of fiber quality attributes in upland cotton (Gossypium hirsutum) germplasm. Int. J. Agric. Biol. 10: 217-220.

Ali MA, Khan IA, Awan SI, Ali S, et al. (2008). Genetics of fibre quality traits in cotton (Gossypium hirsutum L.). Aust. J. Crop Sci. 2: 10-17.

Basra AS (2000). Cotton Fibers: Developmental Biology, Quality Improvement, and Textile Processing. Food Products Press, New York.

Bayles MB, Verhalen LM, Johnson WM and Barnes BR (2005). Trends over time among cotton cultivars released by the Oklahoma Agricultural Experiment Station. Crop Sci. 45: 966-980. http://dx.doi.org/10.2135/cropsci2004.0453

Braden CA and Smith CW (2004). Fiber length development in near-long staple upland cotton. Crop Sci. 44: 1553-1559. http://dx.doi.org/10.2135/cropsci2004.1553

Bridge RR and Meredith WR (1983). Comparative performance of obsolete and current cotton cultivars. Crop Sci. 23: 949-952. http://dx.doi.org/10.2135/cropsci1983.0011183X002300050032x

Bridge RR, Meredith WR and Chism JF (1971). Comparative performance of obsolete and current varieties of upland cotton. Crop Sci. 11: 29-32. http://dx.doi.org/10.2135/cropsci1971.0011183X001100010010x

Carvalho SP (1995). Alternative methods for estimating path coefficients and selection indices under multicollinearity. $\mathrm{PhD}$ thesis. Universidade Federal de Viçosa, Viçosa.

Comstock RE and Robinson HF (1948). The components of genetic variance in populations of biparental progenies and their use in estimating the average degree of dominance. Biometrics 4: 254-266. http://dx.doi.org/10.2307/3001412

Cruz CD (2013). GENES - a software package for analysis in experimental statistics and quantitative genetics. Acta Scientiarum 35: 271-276.

Cruz CD and Carneiro PCS (2003). Modelos biométricos aplicados ao melhoramento genético (volume 2). UFV, Viçosa.

Culp TW and Green CC (1992). Performance of obsolete and current cotton cultivars and Pee Dee germplasm lines of cotton. Crop Sci. 32: 35-41. http://dx.doi.org/10.2135/cropsci1992.0011183X003200010008x

de Magalháes Bertini CHC, Schuster I, Sediyama T, de Barros EG, et al. (2006). Characterization and genetic diversity analysis of cotton cultivars using microsatellites. Genet. Mol. Biol. 29: 321-329. http://dx.doi.org/10.1590/S1415$\underline{47572006000200021}$

Eyherabide GH and Hallauer AR (1991). Reciprocal full-sib recurrent selection in maize: I. Direct and indirect responses. Crop Sci. 31: 952-959. http://dx.doi.org/10.2135/cropsci1991.0011183X003100040023x

Falconer DS (1987). Introdução à genética quantitativa. Trad. Silva MA and Silva JC. UFV, Viçosa.

Falconer DS and Mackay TFC (1996). Introduction to quantitative genetics. Longman, London.

Furtado MR (1996). Selection alternatives in Design I of the Comstock and Robinson, in maize. PhD thesis. Universidade Federal de Viçosa, Viçosa.

Gonçalves GM, Viana AP, Neto FVB, Pereira MG, et al. (2007). Selection and heritability in the prediction of genetic gain in yellow passion fruit. Pesq. Agropec. Bras. 42: 193-198.

Hallauer AR, Carena MJ and Miranda Filho JB (1988). Quantitative genetics in maize breeding. Iowa State University Press, Ames.

IBGE (Instituto Brasileiro de Geografia e Estatística) Censo Agropecuário 2016. Available at [http://www.ibge.gov.br/ home/estatistica/indicadores/agropecuaria/lspa/201607_5]. Accessed September 3, 2016.

Miller PA and Rawlings JO (1967). Selection for increased lint yield and correlated responses in upland cotton, Gossypium hirsutum L. Crop Sci. 7: 637-640. http://dx.doi.org/10.2135/cropsci1967.0011183X000700060024x

Neves LG, Bruckner CH, Cruz CD, Duarte LP, et al. (2011). Genetic gain prediction using the Design I in a population of yellow passion fruit. Rev. Cienc. Agron. 42: 495-501. http://dx.doi.org/10.1590/S1806-66902011000200032

Preetha $S$ and Raveendren TS (2008). Genetic appraisal of yield and fibre quality traits in cotton using interspecific $\mathrm{F}_{2}, \mathrm{~F}_{3}$ and $\mathrm{F}_{4}$ population. Int. J. Integr. Biol 3: 136-142.

Queiroz NL, Filho JLS, Silva MNB, Neto FCV, et al. (2011). Capacidade de combinação entre genótipos de algodoeiro de diferentes bases genéticas para características de fibra. 8 Congresso brasileiro de algodoeiro; COTTON EXPO, 1 , 2011, São Paulo. Evolução da cadeia para construção de um setor forte. Anais: Campina Grande.

Riaz M, Farooq J, Sakhawat G, Mahmood A, et al. (2013). Genotypic variability for root/shoot parameters under water stress in some advanced lines of cotton (Gossypium hirsutum L.). Genet. Mol. Res. 12: 552-561. http://dx.doi. org/10.4238/2013.February.27.4

Genetics and Molecular Research 15 (4): gmr15048146 
Santos RF, Kouri J and Santos JW (2008). Crisis and recovery in the Brazilian market of the agricultural feedstock. In: O Agronegócio do Algodão no Brasil 2. ed. (Beltrão NE de M, Azevedo DMP de, eds.). Embrapa Informação Tecnológica, Brasília.

Schwartz BM and Smith CW (2008). Genetic gain in fiber properties of upland cotton under varying plant densities. Crop Sci. 48: 1321-1327. http://dx.doi.org/10.2135/cropsci2007.05.0308

Smith CW, Hague S, Hequet EF, Thaxton PS, et al. (2008). Development of extra-long staple upland cotton. Crop Sci. 48: 1823-1831. http://dx.doi.org/10.2135/cropsci2008.01.0052

Turner JH, Ramey Jr and Worley Jr (1976). Trends for yield and quality in cotton breeding since 1960. In: Beltwide Cotton Conference, 1976. Proceedings National Cotton Council of America, Las Vegas. 